\section{B A Institute of \\ YK Business Administration \\ TK \\ Karachi \\ Leadership and Ideas for Tomorrow}

Business Review

Volume 2 Issue 2 July-December 2007

7-1-2007

\title{
Entrepreneurial opportunities and market analysis of the Information Technology and Software development sector of Pakistan
}

Toshio Fujita

Institute of Business Administration, Karachi, Pakistan

Hassan Tajuddin

Center of Computer Studies, Institute of Business Administration, Karachi, Pakistan

Follow this and additional works at: https://ir.iba.edu.pk/businessreview

Part of the Business Intelligence Commons, Entrepreneurial and Small Business Operations Commons, Software Engineering Commons, and the Technology and Innovation Commons

\section{(c) (1)}

This work is licensed under a Creative Commons Attribution 4.0 International License.

\section{Recommended Citation}

Fujita, T., \& Tajuddin, H. (2007). Entrepreneurial opportunities and market analysis of the Information Technology and Software development sector of Pakistan. Business Review, 2(2), 122-133. Retrieved from https://doi.org/10.54784/1990-6587.1393

This article is brought to you by iRepository for open access under the Creative Commons Attribution 4.0 License and is available at https://ir.iba.edu.pk/businessreview/vol2/iss2/8. For more information, please contact irepository@iba.edu.pk. 


\title{
DISCUSSION
}

\section{Entrepreneurial Opportunities and Market Analysis of the Information Technology and Software Development Sector of Pakistan}

\author{
Toshio Fujita \\ Institute of Business Administration, Karachi, Pakistan \\ Hassan Tajuddin \\ Center for Computer Studies, \\ Institute of Business Administration, Karachi, Pakistan.
}

\begin{abstract}
This study investigates the Information Technology and the Software 1 Development sector of Pakistan. It discusses the reasons for the lack of trust in Pakistani IT companies and different problems faced by an entrepreneur starting an IT company in Pakistan. The data was analyzed by qualitative content analysis. The findings are discussed with reference to previous research, and implications for entrepreneurial setups are noted.
\end{abstract}

Keywords: IT, Software, Pakistan Markets, Services sector, Entrepreneurship

\section{INTRODUCTION}

The IT industry is a major foreign exchange revenue source for the developing countries including Pakistan, India and other companies in the Indian Subcontinent. In service sector export relating to IT and IT enabled services (ITeS) during 20042005 accounted for US\$ 48.50 million, with targets of $\$ 72$ million in 2005-2006.

According to conservative estimates, there are about $350-500$ software houses in Pakistan working in local and export market. This is creating many jobs for software graduates. This creates a demand for software graduates.

Pakistan is producing about 5,500 IT graduates annually but there is need to utilize their potential and facilitate their innovations.

A detail survey of Pakistan's software market based on top leading 60 software houses representing the total software market showed that there are over 4,000 technical and professional employees with an average of 66 employees in an organization. Out of these software houses $32 \%$ of the software companies reporting annual revenues of more than a million dollar with some reporting more then $\$ 5 \mathrm{M}$, another $36 \%$ between $\$ 200 \mathrm{~K}$ and $\$ 1 \mathrm{M}$, and the rest $32 \%$ less than $\$ 200 \mathrm{~K}$. On the whole these companies had experienced an employment growth of about $27.5 \%$ and a revenue growth of $37.4 \%$ over last year. 
Pakistan produces the best software engineers in the world, having people working with Microsoft, IBM, Oracle and other major software firms. One of the founders of Oracle is also a Pakistan. Thus Pakistan does not lack on talent and has great talent that yet needs to be unleashed.

On the negative aspect our industry is considered to be unreliable and is thus having major image problems. Essentially software in India is being exported at four times the price of Pakistan yet due to the reliability issue the projects are being tendered to India rather than Pakistan.

There have been incidences where projects outsourced to India have been further outsourced to Pakistan. Pakistan thus needs to improve its brand equity in the international software industry.

Companies are now adopting the strategy of developing their own brand rather than developing Pakistan. In doing so, they have opened their offices in Japan, United Arab Emirates, and the United States of America. Companies like AXACT, clickmarks, and net sol have established their brand equity and have proved their worth in the international market.

In order to improve the image of Pakistan various organizations have vested their efforts for the improvement of the IT sector of Pakistan.

This paper studies the various bodies acting to improve our industry and their success factors.

\section{LITERATURE REVIEW}

Various studies have been conducted to study the software industry in Pakistan. The major bodies which have developed the industry include Pakistan Software Houses Association (PASHA), Pakistan Software Export Board (PSEB). Along with this many companies like Microsoft and Intel have also helped develop the industry and have contributed towards studying the industry. Finally international bodies like UNCTAD have also conducted studies on the software sector of Pakistan.

The salient findings and methodologies of prior studies are as follows:

\section{PSEB STUDY (2005):}

This study gives a brief picture of software industry and its potential in the country. According to this study:

The employment growth in software houses is about $27.5 \%$. Average 62 employees work in an organization. 
The revenue growth of software houses is $37.4 \%$ and the revenue from export and domestic market is at $60: 40$ ratios. From export they derive $22.5 \%$ and $38.5 \%$ of the revenue from products and services respectively.

There are four kinds of software business. Domestic-Focused Local Firm, Export Focused Local Firm; Export Focused Foreign Firm, Dedicated Development Center.

Per employee revenue potential is around $\$ 21,800$ per annum.

Pakistan is tier-3 country having more then $\$ 25$ Million in export revenue and over 5 years of industry maturity.

\section{UNCTAD STUDY (2004):}

Comprises review of secondary literature in the Pakistani and international contexts. Salient findings of the study, generally critical of the industry, are:

- Discernable action on only 18 of the $162(11 \%)$ "commitments" of National IT Policy

- Pakistan 76th of 102 countries in Network Readiness Index

- Actual spending under IT Policy 2000 lags allocations, esp. in Exports/eCommerce

- Revenues in Export: $\$ 12.2 \mathrm{M}$ (growth of $84 \%$ ) and Domestic: $\$ 5 \mathrm{M}$ (growth of $49 \%)$

- Current estimate of software exports at about $\$ 12 \mathrm{M}$

- PSEB has 400 members, of which 150 are members of PASHA too

\section{PASHA-LUMS SOFTWARE/IT STUDY (2002):}

Sample size was 16 organizations. Asked questions about domains, revenue sizes, projects acquisition, HR and quality practices etc. The sample was highly biased towards successful software houses. Salient findings are:

- - Average programmer has the potential of generating $\$ 13,000$ in exports every year

- $\quad 75 \%$ of companies have ISO certification and 7\% have CMM certification

- Average stay of an IT professional in a company is about 2 years

- $\quad$ Of the total employment, around $56-58 \%$ were programmers and $11 \%$ QA professionals.

- Larger firms (>PKR 25M) employed double the QA professionals than smaller firms on a percentage basis.

\section{CSP-SEARCC ${ }^{1}$ STUDY OF ICT MANPOWER (2000):}

314 of 441 organizations responded ( $71 \%$ response rate) of which $40.8 \%$ were IT suppliers, $14.5 \%$ public-sector, and $44.7 \%$ private sector end-users. 2375 of 5000 IT

1 This study was conducted by the Computer Society of Pakistan (CSP) in collaboration with South East Asia Regional Computer Confederation and used methodology and instruments that were used among 14 countries of South-East Asia. 
professionals responded ( $46 \%$ response rate) of which $60.3 \%$ worked in development and $39.7 \%$ in services. Some salient findings are:

- $51.3 \%$ IT professionals worked in software development while $6.3 \%$ in IT Mgmt.

- - IT professionals aged between 25-29 (33\%), 20-24 (23\%), and 30-34 (19\%)

- Male : Female ratio is 9:1, with roughly proportional representation in jobs incl. IT mgmt.

- $\quad$ Salary levels: < $\$ 3000$ p.a. (44\%), $\$ 3-5000$ p.a. $(25 \%)$, $\$ 5-8000$ p.a. $(14 \%)$

- $85 \%$ of organizations report shortage of manpower (34\%-extreme, $51 \%$ moderate)

- Top-5 skills in critical shortage: Applications/systems development, network protocol/typologies, dBase, mobile/wireless comm.., and multimedia development

\section{MARKET BASE:}

The market orientation of the software industry in Pakistan is led towards both export and import based. The ratio of export to import based revenues is of 60:40. The figure below shows the Richard Heeks' Taxonomy of Software Businesses, as applied to Pakistan.

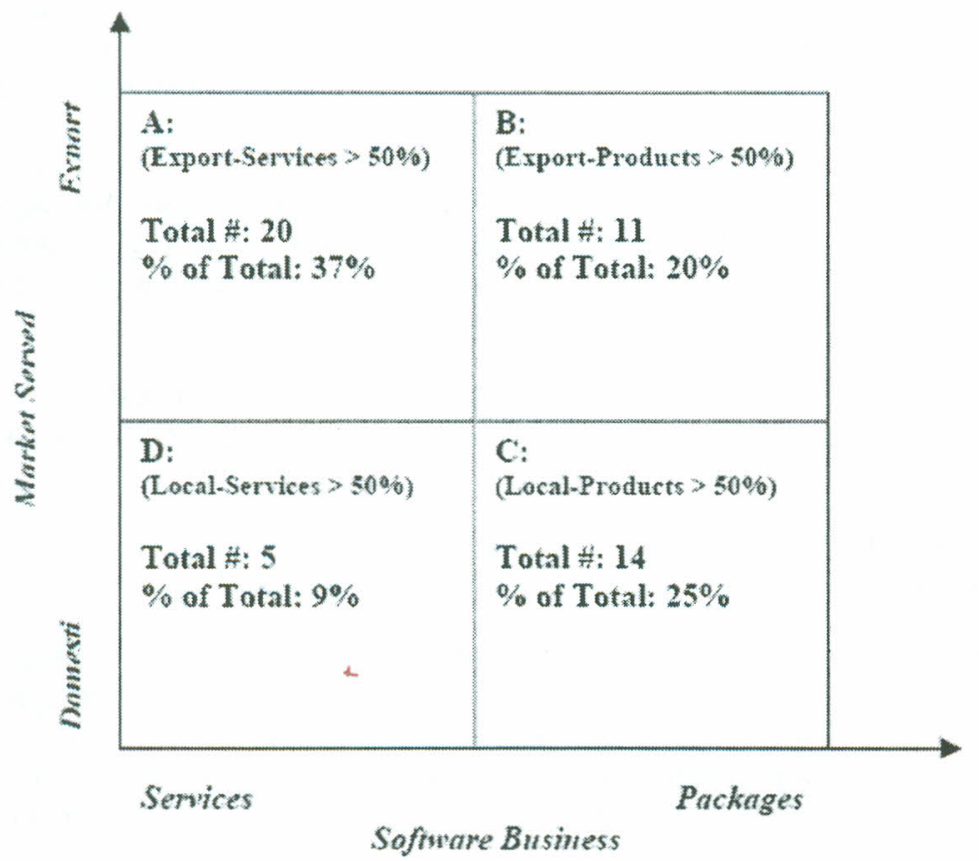




\section{ENTREPRENEURIAL OPPORTUNITIES:}

Windows of opportunities are created by the inefficiencies and the gap of labor costs between the developing and developed countries.

Pakistan today produces about 5,500 IT graduates annually. A total of 1900 cities of Pakistan are connected through the internet.

Focus is shifting towards e-commerce and e-banking. Thus we see a rise in the usage of credit cards and online banking. Along with this we also see and rise in usage of credit cards online for $\mathrm{B} 2 \mathrm{C}$ commerce. Pakistan yet has to develop its $\mathrm{B} 2 \mathrm{~B}$ commerce.

The rapid expansion in the Banking sector and the mergers of various banks in Pakistan has resulted in the need for software to reconcile the data of banks merging together.

Also State Bank of Pakistan has announced that banks have to transfer to the Basil II accord whereby the banks are need of systems implementing the accord.

The stock market of Pakistan has seen a large boom with volume of daily trade on the rise. This has resulted in the explosion of new trading firms. This has in turn created the need for systems to be established to connect to the central depository center.

Also along with this local people have started investing into stocks bringing the need for online systems to allow people to day trade. This facility is currently being provided by AKDtrade and a few others. Many more companies want to shift to the online scenario.

The government of Pakistan has exempted taxes from the IT industry to encourage new setups. Along with this, imports of equipment for this industry is with lower taxes.

\section{DATA AND METHODS:}

\section{SUBJECTS}

A qualitative approach was used, because the aim of the present study was to describe the entrepreneur's experiences. The sample consisted of 10 entrepreneurs $(9$ males, 1 female) in the IT sector from Karachi. The sample selected was a preference sample since this is a preliminary study to bring about new issues in the industry.

All participants who volunteered to participate in interviews by giving written informed consent were interviewed.

Interviews were conducted at a location of the entrepreneurs' choice. Four interviews took place in a quiet restaurant and four at the Institute of Business Administration 
Karachi. The second author interviewed all participants in English. Interviews lasted from 25 minutes to one and a half hours (mean length one hour).A summary of each interview was written including documenting the interviewer's personal impressions, the atmosphere of the interview and other reflections.

\section{METHOD}

The data were collected by semi-structured focused interview. The interview themes reported in the present study were (1) Entrepreneurship opportunities in the IT sector of Pakistan and (2) improvements needed in the IT sector itself. An example of the interview questions concerning opportunities was: 'How did you start up the business?' An example of the interview questions concerning future actions was: 'What do you think should be the role of Pakistan Software Export Board?'

\section{DATA ANALYSIS}

The data were analyzed by the first author using qualitative content analysis recommended by Dey (1993) and Kyngäs and Vanhanen (1999). Phrases and sentences were thematic units of analysis. First, verbatim transcripts and the notes of two interviews, were organized by research questions by writing the original expressions in two tables. Each original expression was coded for easy identification. Then the original expressions were compressed into briefer statements.

Next, these statements were compared with each other and categorized so that expressions with similar content were classified into the same subcategory and named according to its content. Next, the subcategories were abstracted into main categories, separately according to the research questions.

Finally, the main categories of two sub questions were abstracted into the core categories concerning both opportunities and actions.

\section{FINDINGS:}

\section{BRAND ESTABLISHMENT:}

Almost all the candidates interviewed said that they faced problems in establishing the brand of their company.

They stated that the major problem they faced was convincing that despite the fact the company was in Pakistan it followed all standards of excellence world wide.

According to one entrepreneur "We had to work for free for a whole two years before we became established. Now we charge a premium for our high quality product." 


\section{ROLE OF PSEB:}

When asked about the role of Pakistan Software Export Board most entrepreneurs had a good experience with the board. They felt the board was encouraging and helping in terms of getting companies established.

One established entrepreneur on the other hand stated that the major role of PSEB was towards getting small companies to a mark. To attain a status in the international arena, the companies needed to explore on their own.

\section{ROLE OF PASHA:}

Pakistan Software houses association (PASHA) was established to counter runaway programmers and establish standards in the industry. According to the research conducted the role of PASHA was limited in a few hands and lacked the fairness and justice to establish further. PASHA is in fact being used as a tool play for most firms.

PASHA on the other hand does play a role in helping establish standards, whereby companies can more easily become CMMI and ISO certified.

\section{ROLE OF SMEDA:}

Small and Medium Enterprises Development Authority (SMEDA) was established in order to assist entrepreneurs get loans and establish businesses in Pakistan.

Amongst those interviewed none has actually taken any help from SMEDA. Most did not approach SMEDA and for those who did, were not successful in getting help from SMEDA.

\section{ROLE OF MULTINATIONAL FIRMS:}

Multi-national firms play a major role in developing software houses in Pakistan. They hold different seminars and conferences in order to develop the local industry. Mentionable amongst these is Microsoft, which conducts a conference annually that brings the whole IT 'ecosystem' to one place.

These seminars and conferences enable the companies to get new contracts and be aware of the upcoming technologies so they can be up to date with new demands.

\section{COMPANY STRUCTURE, SIZE, ETC.}

Most new startups are small in size with the owners of the company itself as the programmers. The establishment usually has at least one person with connections abroad in order to search for appropriate opportunities and also act as a PR agent. 
Once these companies grow in size they develop new vacancies and advance in terms of HR and accounts.

\section{ENTREPRENEURIAL PERSONALS:}

Most Entrepreneurs are the eldest child and have a good IT background. All of them were graduates and had a good know how of computers. They also had 2-3 years of experience in the industry.

The major motivation regarding starting a new setup was the fact that most of the people interviewed felt that they were being misused and were simply being treated as cheap labour. Thus the industry normally denied respect to such individuals and gave mostly monetary incentives only.

One of the interviewed said that the company he worked for was involved in unethical activities and he did not feel right to work for such a company.

Another incentive felt by those interviewed was the fact that they found high monetary gains in the industry and thus shifted to their own company.

\section{FINANCES:}

In order to arrange for initial finances most companies started very small and the initial startup costs usually came from the savings of the individuals. Thus they did not really need financial support from other sources.

Despite that, they did need familial support to encourage them as the initial startup did not bring in revenues for daily support. And thus they needed an alternative source of funds while the business was being established.

\section{FUTURE RECOMMENDATIONS:}

When asked about the recommendations they could give to governing bodies, they felt that Pakistan should participate more actively in international trade fairs and international tender biddings at government level.

When asked as to how they viewed Pakistan five years from today most were optimistic about the IT sector. They felt that individuals in Pakistan were highly capable of caterings to the international requirements by different standards.

They felt that many more opportunities existed out there and many new entrepreneurial setups were needed to capture the opportunity.

Finally they felt that the development of software technology parks in Pakistan would help develop the Pakistani industry and would also help increase entrepreneurship in Pakistan. 


\section{REFERENCES}

Aberdeen, "Offshore Software Development: Localization, Globalization, and Best Practices in an Evolving Industry", Aberdeen Group Inc., Boston, Massachusetts, USA, 2001

Aberdeen, "Offshore Software Outsourcing Best Practices", Aberdeen Group Inc., Boston, Massachusetts, USA, 2002

Aberdeen, "The Global Sourcing Benchmark Report", Aberdeen Group Inc., Boston, Massachusetts, USA, 2003

Arora et al., "The Globalization of Software: The Case of the Indian Software Industry", Pittsburgh, USA, Carnegie Mellon University, 1997

Arora et al., "The Indian Software Services Industry", Pittsburgh, USA, Alfred P. Sloan Foundation, 2000

Arora, Ashish and J. Asundi, "Quality Certification and the Economics of Contract Software Development: A Study of the Indian Software Service Companies", NBER working paper 7260, Cambridge, MA., 1999

Arora Ashish, V.S. Arunachalam, Jai Asundi, and Ronald Fernandes, "The Indian Software Services Industry: Structure and Prospects", Alfred P. Sloan Foundation, 2001

Arora, Ashish, Alfonso Gambardella, and Salvatore Torrisi, "In the footsteps of the Silicon Valley? Indian and Irish software in the international division of labour", Stanford Institute for Economic Policy Research (SIEPR), Stanford University, CA, USA, June 2001

Bajpai, Nirupam and Vanita Shastri, Software Industry in India: A Case Study, Development Discussion Paper \# 667, Harvard Institute of International Development (HIID), 1998

Barr, Avron, and Shirely Tessler, Developing Sri Lanka's Software Industry Report to the Worldbank, Aldo Ventures, Inc., 2002

Barr Avron, Shirely Tessler, William Miller, Korea and the Global Software Industry: Final Report to the Korean IT Industry Promotion Agency, October 2002

Barr, Avron, Shirley Tessler, and Nagy Hanna, "National Software Industry Development: Considerations for Government Planners" in Electronic Journal for Information Systems in Developing Countries, 2003

Bryan Campbell, "OffShore Development Tips and Techniques: Leveraging Offshore Development Centers", available at (http://www.bryancampbell.com/)

Carmel, Erran, "Taxonomy of New Software Exporting Nations" in Electronic Journal of Information Systems in Developing Countries (EJISDC), 2003 
Carmel, Erran, "The New Software Exporting Nations: Success Factors" in Electronic Journal of Information Systems in Developing Countries (EJISDC), 2003

Chakrabarty, Chandana, and Dilip Dutta, Indian Software Industry: Growth Patterns, Constraints, and Government Initiatives, undated

Commander, Simon, What explains the growth of a Software Industry in Some Emerging Markets, DRC Working Papers \# 22, London Business School, 2003

Computer Society of Pakistan, ICT Manpower and Skills Survey 1999-2000, SEARCC, 2000

Coward, Christopher T., "Looking Beyond India: Factors that Shape the Global Outsourcing Decisions of Small and Medium Sized Companies in America" in Electronic Journal of Information Systems in Developing Countries, 2003

Crone, Mike,"A Profile of the Irish Software Industry, Northern Ireland Economic Research Centre, Belfast, April 2002.

Cusumano, Michael, and Richard W. Shelby, Microsoft Secrets: How The World's Most Powerful Software Company Creates Technology, Shapes Markets, and Manages People, Profile Books, 1995

Cusumano, Michael, Business Models that Last: Balancing Products and Services in Software and Other Industries, Paper \# 197, Center for e-Business @ MIT, 2003

Cusumano, Michael, Alan MacCormack, Chris F. Kremmer, and William Crandal, The Global Survey of Software Development Practices, Paper \# 178, Center for eBusiness@MIT,2003

Cusumano, Michael, The Business of Software, Free Press / Simon Schuster, 2004

Dave, Rishi, "Patterns of Success in the Indian Software Industry", Stanford, USA, undated

D'Costa, "Technology Leapfrogging: Software Industry in India", 2nd International Conference on Technology Policy and Innovation, Calouste Gulbenkian Foundation, Lisbon, 1998.

Dutta, Dilip, Anna Sekhar, Major Indian ICT Firms and Their Approaches Towards Achieving Quality, ASARC Working Paper 2004-04, University of Sydney, 2004

Dutta, Soumitra, Selvan Kulandaiswamy and Luk N. Van Wassenhove, Benchmarking European Software Management Practices, Research Initiative for Software Excellence, INSEAD, undated.

Experts Advisory Cell, "Prospects of IT Industry in Pakistan", Special report by Experts Advisory Cell, Ministry of Industries and Production, May 2004

Hassan, Zahoor Syed, "Software Industry Evolution in a Developing Country: An In Depth Study", Lahore University of Management Sciences, Lahore, Pakistan, 2000 
Richard Heeks, "India's Software Industry, State Policy, Liberalization, and Industrial Development”, Sage Publications, New Delhi, India, 1996

Heeks, Richard, $\square$ Software Strategies in Developing Countries $\square$, Development Informatics, Working Paper Series, Paper No. 6, Institute for Development Policy and Management, University of Manchester, UK, June 1999

Heeks, Richard, Su-Ying Lai \& Brian Nicholson $\square$ Uncertainty and Coordination in Global Software Projects: A UK/India-Centred Case Study, Development Informatics, Working Paper Series, Paper No. 17, Institute for Development Policy and Management, University of Manchester, UK, 2003

Heeks, Richard, "The Uneven Profile of Indian Software Exports", Development Informatics, Working Paper Series, Paper No. 3, Institute for Development Policy and Management, University of Manchester, UK, October 1998

Heeks, Richard, S. Krishna, Brian Nicholson \& Sundeep Sahay, "Synching or Sinking: Trajectories and Strategies in Global Software Outsourcing Relationships", Development Informatics, Working Paper Series, Paper No. 9, Institute for Development Policy and Management, University of Manchester, UK, July 2000

Heeks, Richard \& Brian Nicholson, $\square$ Software Export Success Factors and Strategies in Developing and Transitional Economies $\square$, Development Informatics, Working Paper Series, Paper No. 12, Institute for Development Policy and Management, University of Manchester, UK, 2002

Hohenssohn, Heidi, and Jiayin Hang, Product- and Service Related Business Models for Open Source Software, Siemens Business Services, undated.

Kakola, Timo, "Software Business Models and Contexts for Software Innovation: Key Areas for Software Business Research" in Proceedings of HICSS'03, 2002

Malik, Hameed, IT Sector Study Draft, United Nations Development Program, 2004 MOST, Information Technology Policy, Ministry of Science and Technology, Government of Pakistan, undated

NASSCOM, Strategic Review 2001: The IT Industry in India, 2001

NASSCOM, Strategic Review 2002: The IT Industry in India, 2002

NASSCOM, "E-Commerce Opportunities for India Inc.", NASSCOM-BCG Report, 2002

NASSCOM, Strategic Review 2003: The IT Industry in India, 2003

NASSCOM, Indian ITES-BPO market, 2003

NASSCOM, Strategic Review 2004: The IT Industry in India, 2004

NASSCOM-McKinsey, "NASSCOM-McKinsey Report 2002, Strategies to achieve the Indian IT industry's aspiration", NASSCOM-McKinsey, 2002 
Nicholson, B., and Sundeep Sahay, Building Iran's Software Industry: An Assessment of Plans and Prospects Using the Software Export Success Model, Development Informatics Paper \# 15, 2003

PASHA-LUMS, PASHA-LUMS Study on Software Industry of Pakistan, undated

Posio, Tero, From Project Business to Product Business, Briefing, VTT Technical Research Center for Finland, 2003

Rapp, Willam V., Customized Software: Strategies for Acquiring and Sustaining Competitive Advantage: A Japanese Perspective, Center for Economic Relations with Japan, University of Victoria, 1996

The difference between a successful and unsuccessful organization is the distinction in anticipating and adapting to environmental changes, most importantly, consumers' perceptions. Companies live and die according to the performance of their brands. The most important brand management activity is positioning the brand accurately. A well - positioned brand addresses important consumer benefits; creates an emotional connection with the consumer; and provides flexibility for future growth.

Good to Great, Jim Collins 